\title{
Assessment of the impact of digitalization on the socio-economic development of the country
}

\author{
Margarita Bykova*, Sergey Grachev, Oleg Donichev \\ Vladimir State University named after A.G. and N.G. Stoletovs, Vladimir, Russia
}

\begin{abstract}
This article is devoted to the analysis of the impact of digital transformation processes on the socio-economic development of the country. To study the driving forces of development of the economy of the Russian Federation, a three-factor Cobb-Douglas function was constructed that was modified considering the factor of influence of digitalization on the GDP. Modern trends in the field of competition between cheap, but lowskilled labor, and expensive highly qualified labor, determine the need for analytical studies in the field of changing the existing factors of labor in the process of digital transformation. A special role in construction of a model that reflects the influence of various factors of changes within the framework of the sixth technology revolution is given to assessing the significance of the parameters under study in recent times. Wherein, special attention is focused on the need for further study of time lags reflecting the maximum return on use of labor, capital and digital resources.
\end{abstract}

\section{Introduction}

In the context of the existing financial and economic crisis, as well as its exacerbation due to the coronavirus pandemic, the transfer of a number of sectors of the economy to a remote mode of operation and the transition of most enterprises to the computer method of communication, importance of information and communication networks and use of digital technologies is sharply increasing.

In order to ensure the sustainable functioning of the relations of producers with workers, with consumers of products, as well as with market institutions, an efficient and sustainable digital infrastructure is needed. Moreover, it is in this area that digital innovations shall be constantly formed, making it possible to fulfill their main task - to ensure the viability of the productive forces, allowing in the future to restore the reproductive mode of the national economy and economic growth.

These tasks require an innovative upsurge in all sectors of the country, and this is especially important in the regions.

That is why the management of factors of reproductive orientation and innovative activity of the Russian regions is becoming a paramount goal, and the problem of restructuring the economy based on modern digital technologies is especially aggravated within the current

\footnotetext{
*Corresponding author: margarita93@bk.ru
} 
economic situation and foreign economic conditions [1]. The available experience shows that rapid economic growth rates correlate with a high level of development of the innovative environment: science, digital technologies, knowledge-intensive industries and innovative manufacturing companies.

The theoretical foundations of the production digitalization management are studied in detail, since the flow of capital to an enterprise for the purpose of its innovative diversification depends on the level of demand for products and may fluctuate. However, the threat of losing competitiveness, even within a period of declining market conditions, forces the firm to allocate the necessary funds for innovative developments [2].

Meanwhile, despite the fact that high-tech industries based on digital technologies are developing in the regions, there is not only a digital phenomenon, but also a digital inequality of the constituent entities of the Russian Federation, especially in the production sphere [3].

Such processes are widespread in world practice, since developed countries having sufficient, including financial resources, focus on development of digital innovations and their commercialization, and the less developed ones are forced to be content with borrowing existing innovative developments [4].

It shall be emphasized here that it is the industrial potential of the region, the digitalization of business that can become the basis for its digital technological development. Studies show that in the regions there is a different nature of the impact of information and communication innovations on production processes [5].

Meanwhile, opinions are offered that modernization processes in the field of informatization of regions and management of the information economy are not taking place actively enough in the world [6]. Offers are being made for the strategic development of both individual enterprises and entire industries [7].

Wherein, the digitalization of the production activities of the regions acquires a completely definite reproductive and innovative orientation. Its features are methods of processing big data, cloud technologies, blockchain technologies, digital platforms, the Internet of things, the concept of a smart city and shared consumption [8]. For the accelerated development of production activities, it is necessary to use robotic systems and artificial intelligence, which are the key to increasing labor productivity and economic growth [9].

In this regard, the facts of effective management in the field of information technology, which include the processes, principles, structures and policies of their implementation, acquire a special role. They are closely related to personnel, skills and competencies, as well as information, which is one of the most important corporate assets, and personnel is the main source of threats to security [10]. It shall be noted that we can talk about distribution of roles and responsibilities of personnel involved in working with information systems and technologies for supporting business processes [11].

The main source of economic growth in the country and especially in the regions is their scientific and technological potential (STP) implemented through new information technologies, development of which together leads to formation of a new technology revolution [12]. Management of these processes shall provide for enhanced funding for $\mathrm{R} \& \mathrm{D}$, investment in production and technological complexes of the new technology revolution, in-depth improvement of the digital infrastructure, and formation of an appropriate institutional environment.

A new technology revolution forms a sustainable reproductive growth of the economic system and development. It is determined by the state of the digital transformation taking place in the country [13].

In general, it can be argued that influence of information and communication technologies helps to reduce costs, which leads to increase in labor productivity and enables the enterprise to produce more products, expand economic reproduction [14]. 
The processes of managing successful digital transformation are gaining particular importance in the regions. The highest results here are demonstrated by the indicators of the so-called digital infrastructure capital that includes the degree of access to broadband Internet, the intensity of use of server equipment and local area networks at regional enterprises [15].

Wherein, the most significant is the fact that under the influence of infrastructural digital capital in the regions there is a transition from a production function with constant returns to a production function with increasing returns.

The impact of digital infrastructure and infrastructure assets on development of economic systems has been studied quite widely. For example, it is concluded that development of the ICT infrastructure, for both fixed broadband users and Internet users, leads to increase in the GDP per capita [16].

Digital infrastructure capital is actively manifested in the digital component of the population life quality. It shall also consider the quality of working life and the social sphere, the security of information activities [17].

The problems of the population life quality in the context of digitalization are in the focus of attention of Western scientists as well. Some of them clearly highlight the features of ensuring the digital well-being of residents [18], or pay more attention to the impact on life of the existing regional digital inequality [19].

As we have already noted, digital infrastructure plays a significant role in shaping the reproductive orientation of the socio-economic development of regions and overcoming their digital inequality. However, in these conditions, it is necessary to highlight the infrastructure of the communications industry, which is not only a significant factor in accelerating development, but also contributes to strengthening the integrity of the economic space of Russia [20].

Similar differences exist in the West and are actively discussed by scientists. For example, the digital inequality in the services of urban and rural settlements is analyzed in detail, especially from the standpoint of introduction of broadband reception, government management tools are considered to eliminate the digital inequality [21].

Transition to the sixth technology revolution for the Russian Federation means a reorientation to robotics, nanotechnology, and etc.

To ensure development of the country in step with the times, it is necessary to reorient areas of activity to relevant areas. It shall be noted that competent development within the framework of the new sixth technology revolution is possible only after mastering the previous fifth technology revolution. Wherein, the degree of development of the fifth technology revolution shall be no worse than that of developed countries.

Therefore, in order to achieve results in the directions of the sixth technology revolution that have already entered the global economic world, the country needs to master the directions of the previous technology revolution and level the existing negative gaps with those countries that achieved better results at an earlier stage of economic development.

The change in the dominant technology revolutions in the global economy is a predetermining factor in ensuring unevenness of the course of scientific and technological progress. Wherein, the success of a country within the framework of the functioning of a specific technology revolution depends on many conditions, one of which is sufficient funding for innovative activities in the country, since it is the innovative sphere of activity that predetermines the possibility of the country's overall development in the context of a specific orientation of the production and economic sphere.

The study of T.V. Mirolyubova and M.V. Radionova [22] analyzes the importance of the sector of information and communication technologies, as well as the factors of transformation of the digital sphere, considered at the level of the regional economy. According to the author's interpretation of the concept of "digital transformation" based on 
the study of the authors, the fundamental role of the ICT sector for regional economic development shall be noted.

As before, the gross domestic product is one of the main indicators of socio-economic development. Wherein, in modern conditions, it is impossible not to consider the role of the level of digitalization in the country development.

\section{Study Methods}

Since the limited statistical information predetermines the need to choose an adequate statistical study toolkit, within the framework of the study of individual factors for the change in the ratio of operating forces in the country's economy, the Cobb-Douglas model was chosen, but in a modified form. The standard model of influence involves the assessment of labor factors and on the results of production activities.

To study the driving forces of development of the economy of the Russian Federation, a three-factor Cobb-Douglas function was constructed that was modified considering the factor of influence of digitalization on the GDP. Therefore, factors such as investment in fixed assets (K), average wages (L), and the cost of information and communication technologies (C) were identified as explanatory variables. Therefore, in general form, the modified CobbDouglas function takes the form (1):

$$
Y=\alpha_{0} K^{\alpha_{1}} L^{\alpha_{2}} C^{\alpha_{3}}
$$

where $\alpha_{0}$ - is technological coefficient;

$\alpha_{1}$-capital elasticity coefficient;

$\alpha_{2}$-labor elasticity coefficient;

$\alpha_{3}$-digital transformation elasticity coefficient.

In order for the constructed model to be adequate and reflect the latest changes in production volumes across the country, including through digitalization, the analytical period from 2010 to 2019 was applied.

Since the question of the need to bring the initial data to comparable prices in scientific circles is still open, this standardization of the initial parameters was not carried out within the framework of the paper.

\section{Study Results}

The initial data for constructing the modified Cobb-Douglas function determined from the official statistical collections [23] are shown in Table 1.

The accrued wages of employees for the full range of organizations in the Russian economy as a whole were determined for construction of the model as the product of the average monthly nominal accrued wages by the number of months in each analyzed period and the average annual number of employees.

Table 1. Initial data for constructing the model.

\begin{tabular}{|c|c|c|c|c|}
\hline Year & $\begin{array}{c}\text { The value of } \\
\text { the GDP of } \\
\text { the Russian } \\
\begin{array}{c}\text { Federation in } \\
\text { current prices, } \\
\text { billion rubles }\end{array}\end{array}$ & $\begin{array}{c}\text { Fixed } \\
\text { capital } \\
\text { investment } \\
\text { s, billion } \\
\text { rubles }\end{array}$ & $\begin{array}{c}\text { Accrued wages of } \\
\text { employees for a full } \\
\text { range of organizations in } \\
\text { the whole economy of } \\
\text { the Russian Federation, } \\
\text { million rubles }\end{array}$ & $\begin{array}{c}\text { Internal costs for research } \\
\text { and development in the } \\
\text { priority area "Information } \\
\text { and telecommunication } \\
\text { systems" in current prices, } \\
\text { million rubles }\end{array}$ \\
\hline 2010 & $46,308.5$ & 9,152 & 16990479.6 & 38128.8 \\
\hline
\end{tabular}


Continuation of table 1 .

\begin{tabular}{|l|l|l|l|l|}
2011 & $60,114.0$ & 11,036 & 18992547.2 & 46609.9 \\
\hline 2012 & $68,103.4$ & 12,569 & 21719358.0 & 61966.0 \\
\hline 2013 & $72,985.7$ & 13,450 & 24274879.1 & 60031.7 \\
\hline 2014 & $79,030.0$ & 13,903 & 26443001.2 & 70631.5 \\
\hline 2015 & $83,087.4$ & 13,897 & 29575473.0 & 74555.8 \\
\hline 2016 & $85,616.1$ & 14,749 & 31745209.0 & 77932.0 \\
\hline 2017 & $91,843.2$ & 15,967 & 33720907.0 & 81390.7 \\
\hline 2018 & $103,861.7$ & 17,782 & 37547722.7 & 76116.1 \\
\hline 2019 & $109,241.5$ & 19,329 & 40819445.9 & 88471.6 \\
\hline
\end{tabular}

To find the coefficients $\alpha_{0}, \alpha_{1}, \alpha_{2}, \alpha_{3}$ the modified Cobb-Douglas function was linearized by logarithm using the following formula:

$$
\operatorname{Ln}(Y)=\ln \left(\alpha_{0}\right)+\alpha_{1} \ln (K)+\alpha_{2} \ln (L)+\alpha_{3} \ln (C)
$$

After these transformations and potentiation of the constant coefficient $\alpha_{0}$ the CobbDouglas function of the following form was obtained (Fig. 1):

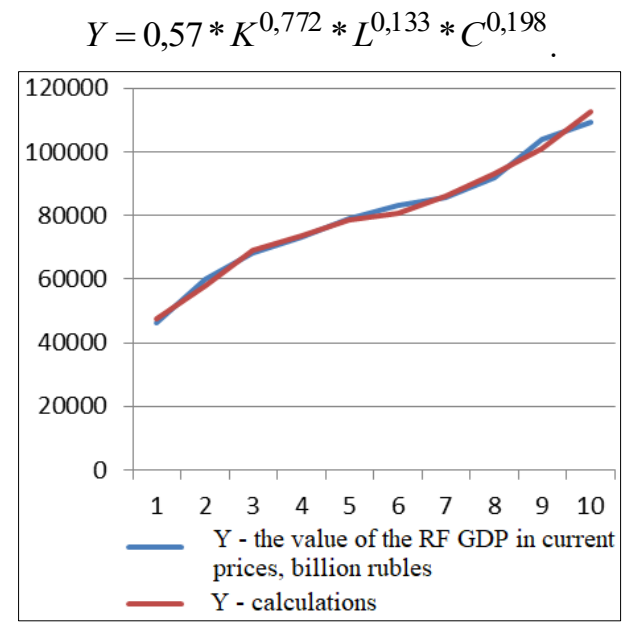

Fig. 1. Graphical comparison of the calculated value of the function and the original statistical data.

To assess the adequacy of the constructed model, the Fisher criterion was used.

Since the calculated value $(\mathrm{F}=215.11)$ significantly exceeds the tabulated value $(\mathrm{F}=$ 9.78), the constructed function with a reliability of $99 \%$ corresponds to the initial data and can be used for further analysis of the efficiency of labor resources, capital and the factor of digitalization.

As part of the paper, the average return for the analyzed factors of production was calculated using the following formulas:

$$
\mu_{\kappa}=\frac{Y(K ; L ; C)}{K}=\frac{\alpha_{0} K^{\alpha_{1}} L^{\alpha_{2}} C^{\alpha_{3}}}{K}=\alpha_{0} K^{\alpha_{1}-1} L^{a_{2}} C^{\alpha_{3}}
$$

The same way,

$$
\mu_{L}=\frac{Y(K ; L ; C)}{L}=\alpha_{0} K^{\alpha_{1}} L^{a_{2}-1} C^{\alpha_{3}}
$$




$$
\mu_{c}=\frac{Y(K ; L ; C)}{C}=\alpha_{0} K^{\alpha_{1}} L^{a_{2}} C^{\alpha_{3}-1}
$$

The calculation results are provided in Table 2 .

Table 2. Initial data for constructing the model.

\begin{tabular}{|c|c|c|c|}
\hline Year & $\mu \mathrm{K}$ & $\mu \mathrm{L}$ & $\mu \mathrm{C}$ \\
\hline 2010 & 5.1989 & 0.0028 & 1.2479 \\
\hline 2011 & 5.2603 & 0.0031 & 1.2455 \\
\hline 2012 & 5.4992 & 0.0032 & 1.1154 \\
\hline 2013 & 5.4608 & 0.0030 & 1.2235 \\
\hline 2014 & 5.6607 & 0.0030 & 1.1142 \\
\hline 2015 & 5.8077 & 0.0027 & 1.0825 \\
\hline 2016 & 5.8342 & 0.0027 & 1.1042 \\
\hline 2017 & 5.8253 & 0.0028 & 1.1428 \\
\hline 2018 & 5.6894 & 0.0027 & 1.3292 \\
\hline 2019 & 5.8147 & 0.0028 & 1.2704 \\
\hline
\end{tabular}

The calculation results show that the average return on capital and on use of digitalization significantly exceeds the return on use of the labor factor. Therefore, the country's economy can be characterized as intensive, that is, labor-saving, based on introduction of digital technologies.

\section{Discussion of Results}

The calculation results show that the average return on capital and on use of digitalization significantly exceeds the return on use of the labor factor. Therefore, the country's economy can be characterized as intensive, that is, labor-saving, based on introduction of digital technologies.

Modern trends in the field of competition between cheap, but low-skilled labor, and expensive highly qualified labor, determine the need for analytical studies in the field of changing the existing factors of labor in the process of digital transformation. Due to introduction of digitalization, the ways of doing business are changing, development priorities of certain areas, and approaches to work are changing. The active development of labor-saving technologies in the context of the country's digitalization is, on the one hand, a factor ensuring the further introduction of digital technologies, and on the other hand, a prerequisite for the digital transformation process.

\section{Conclusion}

Based on the study, the following conclusions were determined: the vector of further development of the country's economy is predetermined by development of digital technologies as part of transition to the sixth technology revolution. Particular importance in the context of digital transformation shall be given to the labor factor. Improving the qualifications of personnel and reorienting the labor market to a more expensive and skilled workforce, as well as the active introduction of digital technologies will allow achieving the maximum growth in the country's welfare in the face of changing driving forces for development of the economy of the Russian Federation. A further direction of the study is seen in the analysis of time lags, reflecting the maximum return on use of a particular factor in socio-economic development, as well as the search for a combination of the analyzed factors that provide the maximum impact on the value of the gross regional product. 


\section{References}

1. O. S. Mariyev, K. M. Nagiyeva, V. L. Simonova, Upravleniye faktorami innovatsionnoy aktivnosti rossiyskikh regionov na osnove ekonometricheskogo modelirovaniya, Upravlenets, 11(1), 57-69 (2020). Access mode: http://doi.org/10.29141/2218- 50032020-11-1-6

2. M. Yu. Arkhipova, V. P. Sirotin, Regional'nyye aspekty razvitiya informatsionnokommunikatsionnykh $i$ tsifrovykh tekhnologiy, Ekonomika regiona, 15(3), 670-683 (2019). Access mode: DOI: 10.17059/2019-3-4

3. A. A. Urasova, Regional'nyy promyshlennyy kompleks $v$ tsifrovuyu epokhu: informatsionno-kommunikatsionnoye izmereniye, Ekonomika regiona, 15(3), 684-694 (2019). Access mode: DOI: 10.17059/2019-3-5.

4. J. W. Poindexter, Factory of the Future Vision and Strategic Thrust Plan (2018). Access mode:http://www.dodmantech.com/ManTechPrograms/Files/AirForce/Cleared_Factor y_of_the_Future_Dist_A_ITI_Short_Presentation.pdf

5. J. G. Williamson, Regional Development and the Process of National Development: A Description of the Patterns, Economic Development and Cultural Change, 13, 1-84 (1965)

6. Ye. V. Popov, Ekonomicheskiye instituty tsifrovizatsii khozyaystvennoy deyatel'nosti, Upravlenets, 10(2), 2-10 (2019). Access mode: DOI: 10.29141/2218-5003-2019-10-21

7. C. Dirican, The Impacts of Robotics, Artificial Intelligence On Business and Economics, Procedia - Social and Behavioral Sciences, 195, 564-573 (2015)

8. D. Henriques, R. Pereira, R. Almeida, M. Mira da Silva, IT Governance Enablers, Foresight and STI Governance, 14(1), 48-59 (2020). Access mode: DOI: 10.17323/2500-2597.2020.1.48.59

9. L. Higgins, D. Sinclair, A new look at IT governance, Journal of Corporate Accounting \& Finance, 19(5), 31-36 (2008). Access mode: DOI: 10.1002/jcaf.20415

10. V. S. Uskov, Scientific and Technological Development of the Russian Economy in the Transition to a New Technological Order, Economic and Social Changes: Facts, Trends, Forecast, 13(1), 70-86 (2020). Access mode: DOI: 10.15838/ esc.2020.1.67.4

11. B. G. Choy, Random Interaction Effect of Digital Transformation on General Price Level and Economic Growth, Foresight and STI Governance, 14(1), 29-47 (2020). Access mode: DOI: 10.17323/2500-2597.2020.1.29.47

12. General Price Level and Economic Growth, Foresight and STI Governance, 14(1), 2947 (2020). Access mode: DOI: 10.17323/2500-2597.2020.1.29.47

13. M. Draco, R. Sadun, J. van Reenen, Productivity and ICT: A Review of the Evidence, CEP Discussion Paper 749 (Center for Economic Performance, 2015)

14. T. V. Kramin, A. R. Klimanova, Razvitiye tsifrovoy infrastruktury v regionakh Rossii, Terra Economicus, 17(2), 60-76 (2019). Access mode: DOI: 10.23683/2073- 66062019-17-2-60-76

15. R. P. Pradhan, G. Mallik, T. P. Bagchi, Information communication technology (ICT) infrastructure and economic growth: A causality evinced by cross-country panel data, IIMB Management Review, 30(1), 91-103 (2018)

16. G. P. Litvintseva, A. V. Shmakov, Ye. A. Stukalenko, S. P. Petrov, Otsenka tsifrovoy sostavlyayushchey kachestva zhizni naseleniya v regionakh Rossiyskoy Federatsii, Terra 
Economicus, 17(3), 107-127 (2019). Access mode: DOI: 10.23683/2073-6606-201917-3-107-127

17. R. Boarini, et al., What makes for a better life?: The determinants of subjective wellbeing in OECD countries - Evidence from the Gallup World Poll, OECD Statistics Working Papers, 2012/03 (2012). Access mode: DOI: 10.1787/5k9b9ltjm937-en

18. M. R. Szeles, New insights from a multilevel approach to the regional digital divide in the European Union, Telecommunications Policy, 42(6), 452-463 (2018)

19. A. G. Gryaznova, V. S. Antonyuk, Ye. L. Korniyenko, Regional'nyye problemy upravleniya infrastrukturoy svyazi v tsifrovoy ekonomike, Upravlenets, 10(4), 38-50 (2019). Access mode: DOI: 10.29141/2218-5003-2019-10-4-4

20. F. Williams, L. Philip, J. Farrington, G. Fairhurst, "Digital by Default" and the "hard to reach": Exploring solutions to digital exclusion in remote rural areas, Local Economy, 31(7), 757-777 (2016). Access mode: DOI: 10.1177/0269094216670938

21. Y. Kim, P. F. Orazem, Broadband internet and new firm location decisions in rural areas, American Journal of Agricultural Economics, 99(1), 285-302 (2017). Access mode: DOI: 10.1093/ajae/aaw082

22. T. V. Mirolyubova, M. V. Radionova, Rol' sektora IKT i faktory tsifrovoy transformatsii regional'noy ekonomiki v kontekste gosudarstvennogo upravleniya, Vestnik Permskogo universiteta, Ser. «Ekonomika», 15(2), 253-270 (2020). Access mode: DOI: 10.17072/1994-9960-2020-2-253-270 